\title{
KÜSIMUSED EESTI LAPSELE SUUNATUD KÕNES LeEDU JA VENE KEele tAUSTAL
}

\author{
Helen Kõrgesaar
}

Ülevaade. Eesti hoidjakeele uurimine on valdkond, millega on põhjalikumalt tegelema hakatud alles viimasel kümnendil, seetõttu leidub hoidjakeele tasandeid, mille kohta info on napp või puudub üldse. Siinne artikkel annab esmalt ülevaate uurimusest, mis vaatleb eesti hoidjakeeles kasutatavaid küsilausungeid teiste keelte (vene, leedu, aga ka prantsuse ja Austria saksa) taustal. Seejärel kirjeldatakse kaht tulemusi täpsustavat kontrolluuringut. Artiklist selgub ka, kuidas jagunevad küsilausungid eesti, vene ja leedu hoidjakeeles nende positsioonist, pragmaatilisest rollist, funktsioonist ja struktuurist lähtuvalt.

Võtmesõnad: keeleomandamine, pragmaatika, eesti keel, vene keel, leedu keel

\section{Sissejuhatus}

Viimase kümne aasta jooksul on eesti laste keeleomandamise uurimise juures hakatud üha suuremat tähelepanu pöörama ka suhtluse teisele poolele - lastele suunatud kõnele ehk hoidjakeelele. Hoidjakeel on dünaamiline kõneregister, mida kasutab täiskasvanu lapsega kõneldes. Hoidjakeele sõnavara ja suhtlemisstrateegiad on individuaalsed ning muutuvad lapse kasvamisega. Varasema perioodi hoidjakeelt iseloomustavad arvukad kordused, täiskasvanule suunatud kõnega võrreldes lühemad laused, mis on oma suhtluseesmärgi tõttu pigem küsi- või väitlaused, ning onomatopoeetiliste sõnade ja deminutiivide rohkus. Siinse artikli kontekstis on hoidjakeele all silmas peetud varajase perioodi hoidjakeelt (ingl baby talk), mida vanem kõneleb alla kolmeaastase lapsega.

Kuigi esimesi vihjeid lastele suunatud kõne kohta võib leida juba ligi saja aasta tagusest kirjutisest (Mägiste 1924), jäävad esimesed tänapäevased hoidjakeele käsitlused tõepoolest veidi enam kui kümne aasta tagusesse aega (Tulviste 2000, Pajusalu 2001, Argus 2003). Nüüdseks on eesti lastekeele uurijad jõudnud üksmeelsele seisukohale, et laste- ja hoidjakeel on teineteisega tihedalt seotud ning 
paremaid tulemusi on võimalik saada, kui üht uurides vaadeldakse paralleelselt ka teise andmeid.

Ühena esimestest hakkas lapsele suunatud kõne uurimisega tegelema Tiia Tulviste, kes on uurinud vanema (enamasti ema) vestlusstrateegiaid lapsega kõneldes. Tulviste paigutas eesti hoidjakeele kohe ka teiste keelte konteksti, kõrvutades kohalikku keelematerjali USA, Soome ja Rootsi omaga (Tulviste 2000, Tulviste, Kants 2001, Tulviste jt 2002), samuti on ta vaadelnud vestlusstrateegiaid eri situatsioonides, nagu söögilauavestlused või suhtlemine puslede kokkupanemisel (Tulviste 2000, Tulviste, Mizera 2002).

Eesti hoidjakeeles on palju uurimata valdkondi. On kirjeldatud väikelastele suunatud kõnet ning seda pigem morfoloogia ja sõnavara koostise seisukohast, kuid täiesti käsitlemata on jäänud näiteks teismelistele suunatud kõne, samuti on väga vähe tegeletud hoidjakeele pragmaatikaga. Siinse artikli eesmärk on kirjeldada eesti lapsele suunatud kõnes esinevaid küsimusi ja nende tüüpe teiste keelte taustal, esitada eesti küsimuste hulga ja liikide kohta andmeid võrdluses teiste keeltega (vene, leedu) ning seejärel vaadelda edasiarendatud liigituse alusel lähemalt eesti küsimusi. Lõpuks kõrvutatakse andmeid teiste eesti laste ja nende vanemate kõne kontrollmaterjaliga.

Analüüs võimaldab esiteks asetada eesti hoidjakeele laiemasse konteksti ning vaadelda eesti vanemate keelekasutust lapsega rääkides, pidades silmas rahvuslikke ja kultuurilisi eripärasid. Kuna esmase keelematerjali analüüsist selgus, et eesti hoidjate keelekasutus erineb vene ja leedu hoidjate omast, ongi siinse artikli eesmärk selgitada välja, kas eesti hoidjakeel sarnaneb oma vestlusstrateegiatelt pigem germaani ja romaani või meile geograafiliselt lähedasemate balti ja slaavi keelte omaga. Teiseks annab keelematerjali uurimine andmeid selle kohta, mis funktsiooni küsimused vanema kõnes täidavad ja kuidas küsimuste eri liigid vanema kõnes jaotuvad.

\section{Teoreetiline lähtepunkt ja kõneandmed}

Eesti hoidjakeele vestlusstrateegiad on ainest pakkunud ka teistele uurijatele. 2012. aastal viidi läbi ühisuurimus, kus võrreldi eesti, vene ja leedu hoidjakeele andmeid ja analüüsiti eesti, vene ja leedu vanemate küsilausungeid 1;8-2;8 vanustele lastele suunatud kõnes (Kazakovskaja jt 2012). Uurimuse varasemas etapis (Kazakovskaja, Balčiūnienè 2012b) olid selgunud teatavad sarnasused vene ja leedu hoidjate keelekasutuses (näiteks kasutab vanem rohkesti küsimusi, millest enam kui 85\% on vestlusküsimused) ${ }^{1}$; eesti hoidjakeel kaasati uurimusse eesmärgiga vaadata, kas võiks väita, et kõigi kolme keele hoidjakeel kannab teatud kultuurilist ühismõju ehk on mõjutatud meie ühisest nõukogude minevikust. Siinse artikli aluseks olnud ühisuurimuse tarbeks liigitas küsimusi vene keele dialoogides Viktoria Kazakovskaja, leedu keele dialoogides Ingrida Balčiūnienè ja eesti keele materjalis siinse artikli autor Helen Kõrgesaar.

Laste ja vanemate vahelise spontaanse kõne dialoogi oli uuritavas vanusevahemikus lindistatud iga kuu (ainult eesti lapse kohta puudus lindistus vanuses 2;2). Eesmärk oli vaatluse alla võtta iga lindistuse 300 esimest küsimust, mis võimaldaks 
määrata ka nn initsiatiivküsimused e vestlust algatavad küsimused. Vene ja leedu lindistustes nii ka tehti, kuid eesti dialoogides ei olnud niisugune valik võimalik, kuna ainult kahes lindistuses esines üle 300 küsimuse. Seetõttu võeti vaatluse alla kõik eesti dialoogides esinenud küsimused. Tabel 1 annab ülevaate sellest, kuidas kõneandmed eri keelte vahel jagunesid. Samuti on tabelis esile toodud, kui suur oli küsimuste osakaal kõigist täiskasvanu lausungitest.

Nii vene kui ka leedu keelematerjal hõlmas 13 tunniajast lindistust, millest oli vaatluse all niisiis 300 esimest küsimust (kokku 3900 küsimust mõlema keele kohta). Iga keele vestlusmaterjal oli pärit ühe lapse ja vanema vahelistest dialoogidest. Kõik kolm last olid ükskeelsest perest, olid normikohase arenguga, elasid oma kodumaa suuruselt teises linnas (Peterburi, Kaunas, Tartu) ning olid pere ainsad lapsed. Vaatlusaluse vene lapse vestluspartneriks dialoogides oli tema vanaema, leedu lapsega vestles ema ning eesti lapse lindistustes oli vestluse teiseks osapooleks enamasti ema, kolmes lindistuses ka isa. Eesti keelematerjal koosnes umbes 10 dialoogitunnist, kuna kõik lindistused ei olnud päris tunniajased. Kokku esines eesti täiskasvanu kõnes 957 küsimust. $^{2}$

Tabel 1. Analüüsitud küsimuste hulk lindistustes ning küsimuste osakaal kõigi vanema lausungite hulgas (Kazakovskaja jt 2012)

\begin{tabular}{|l|c|c|c|c|c|c|}
\hline \multirow{2}{*}{$\begin{array}{c}\text { Lapse } \\
\text { vanus }\end{array}$} & $\begin{array}{c}\text { Küsimusi } \\
\text { hoidja- } \\
\text { keeles }\end{array}$ & $\begin{array}{c}\text { Küsimuste osakaal } \\
\text { kõigist vanema } \\
\text { lausungitest }\end{array}$ & $\begin{array}{c}\text { Küsimusi } \\
\text { hoidja- } \\
\text { keeles }\end{array}$ & $\begin{array}{c}\text { Küsimuste osakaal } \\
\text { kõigist vanema } \\
\text { lausungitest }\end{array}$ & $\begin{array}{c}\text { Küsimusi } \\
\text { hoidja- } \\
\text { keeles }\end{array}$ & $\begin{array}{c}\text { Küsimuste osakaal } \\
\text { kõigist vanema } \\
\text { lausungitest }\end{array}$ \\
\hline $1 ; 8$ & 300 & $45,4 \%$ & 300 & $69,7 \%$ & 256 & $34,7 \%$ \\
\hline $1 ; 9$ & 300 & $43,9 \%$ & 300 & $65,8 \%$ & 66 & $24,2 \%$ \\
\hline $1 ; 10$ & 300 & $56 \%$ & 300 & $70 \%$ & 221 & $31 \%$ \\
\hline $1 ; 11$ & 300 & $50,4 \%$ & 300 & $91,4 \%$ & 61 & $43,9 \%$ \\
\hline $2 ; 0$ & 300 & $46,5 \%$ & 300 & $62,5 \%$ & 394 & $22,1 \%$ \\
\hline $2 ; 1$ & 300 & $59,6 \%$ & 300 & $85,7 \%$ & 674 & $15,8 \%$ \\
\hline $2 ; 2$ & 300 & $55 \%$ & 300 & $90,7 \%$ & - & - \\
\hline $2 ; 3$ & 300 & $55,5 \%$ & 300 & $42,5 \%$ & 43 & $33,3 \%$ \\
\hline $2 ; 4$ & 300 & $58,9 \%$ & 300 & $79 \%$ & 47 & $25,8 \%$ \\
\hline $2 ; 5$ & 300 & $53,7 \%$ & 300 & $69,7 \%$ & 88 & $25,6 \%$ \\
\hline $2 ; 6$ & 300 & $58,5 \%$ & 300 & $65,5 \%$ & 53 & $23,1 \%$ \\
\hline $2 ; 7$ & 300 & $47,9 \%$ & 300 & $70,1 \%$ & 89 & $31,7 \%$ \\
\hline $2 ; 8$ & 300 & $42,5 \%$ & 300 & $72 \%$ & 66 & $34,2 \%$ \\
\hline Keskmine & - & $51,8 \%$ & - & $71,9 \%$ & - & $28,8 \%$ \\
\hline & & & & & & \\
\hline
\end{tabular}

Uurimusest ilmnes, et kui vene hoidjakeeles esines tunniajases lindistuses keskmiselt $51,8 \%$ küsimusi ja leedu omas koguni $71,9 \%$ kõigist vanema lausungitest, siis eesti hoidjakeel koosnes küsimustest vaid $28,8 \%$ ulatuses. Kui vene ja eriti leedu hoidjakeel on üles ehitatud küsimustele, siis eesti täiskasvanu kasutab lapsega kõneldes peamiselt väiteid ja käskluseid.

Wolfgang U. Dressleri töörühma varasemast uurimusest (Kilani-Schoch jt 2009) selgus, et nii prantsuse kui ka Austria saksa hoidjakeeles kasutatakse samuti

\footnotetext{
2 Nii eesti, vene kui ka leedu keelematerjal on pärit CHILDESi lastekeele andmepangast. Eesti materjal on andmepangas Vija alamkorpusena (kogunud Maigi Vija), vene keelematerjal oli kogutud Natalja Gagarina juhatusel ning leedu pikiuuringu tarbeks oli materjali kogunud Ingrida Balčiūnienè.
} 
rohkesti mitteküsivaid kordusi ja vähem küsimusi, mistõttu eesti keel paigutus mainitud ühisuurimuse valguses pigem meist geograafiliselt kaugemate germaaniromaani keelte konteksti. Ka siinkirjutaja kogutud esmased andmed eesti hoidjakeele kohta kinnitavad, et täiskasvanu kasutab 4-aastase lapsega kõneldes suurel hulgal mitteküsivaid kordusi, korrates peamiselt üle lapse vastuseid küsimustele, aga ka küsimusi endid, seevastu vestluses teise täiskasvanuga esines vaid mõni üksik kordus (1).

(1) LAPS: mis see on siis?

EMA: no mis see on?

LAPS: kaubaauto.

EMA: kaubaauto.

Lapsega kõneldes kordas täiskasvanu ühest küljest üle sõnu, mida pidas vajalikuks lapsel kinnistada, teisest küljest korrati aga ka neid sõnu, mis lapsel kindlasti selged olid, andmaks tagasisidet, et vastus on õige ja laps on õigel teel (Kõrgesaar 2007). Tuginedes nendele andmetele kui ainsatele selles eesti hoidjakeele valdkonnas, võib tõepoolest väita, et eesti lastele suunatud kõnes on kordused väga sagedad.

\subsection{Hoidjakeele küsimuste liigitus}

Analüüsi aluseks olnud küsimuste liigituse on varasemate, vene ja leedu hoidjakeelt käsitleva uurimuse tarbeks ${ }^{3}$ välja arendanud Kazakovskaja ja Balčiūnienė (2011, 2012a, 2012b). Sama liigitust kasutasime ühiselt ka vene, leedu ja eesti hoidjakeeli võrdlevas uurimuses ning hiljem on seda mugandanud ning eesti lastekeele uurimiseks kohandanud siinse artikli autor. Liigitus koosneb viiest eri tasemest, jagasime küsimused esmalt positsiooni, seejärel pragmaatilise rolli, funktsiooni, struktuuri ja viimaks vormi järgi. Siinkohal pean oluliseks lugejale selgitada, mida täpselt on liigituse iga jaotuse all (vt joonis 1) silmas peetud, mistõttu olen täiendanud autorite kirjeldust (Kazakovskaja, Balčiūnienẻ 2012b: 201-203) omapoolsete selgitavate kommentaaride ning eesti keele näidetega:

1) positsioon vestluses - kas tegemist on algatus- (ingl initial) või reaktsiooniküsimusega (reaction). Algatusküsimus on vestlust/lindistust alustav küsimus ning enamasti saab neid lindistuse jooksul esineda vaid ühel korral. Samas on mõnes lindistuses tehtud paus ning hiljem vestlust jätkates alustatud taas algatusküsimusega, nt Noh, mida sa sïs nüüd teha tahaksid? Reaktsiooniküsimus on küsimus, mille vanem esitab reaktsioonina lapse eelnevale lausungile;

2) pragmaatiline roll - algatusküsimused saavad oma pragmaatilise rollijärgi ollagi ainult vestlusküsimused (conversational), samas kui reaktsiooniküsimused võivad lisaks sellele olla ka metadiskursiivsed (metadiscurive), mille all mõistetakse küsimusi, mis täpsustavad lapse öeldut. Vanem küsib üle, kui ta ei saanud päris täpselt aru, mida laps ütles, või parandab öeldu sisu, nt Mida-mida, kuidas sa ütlesid?; 


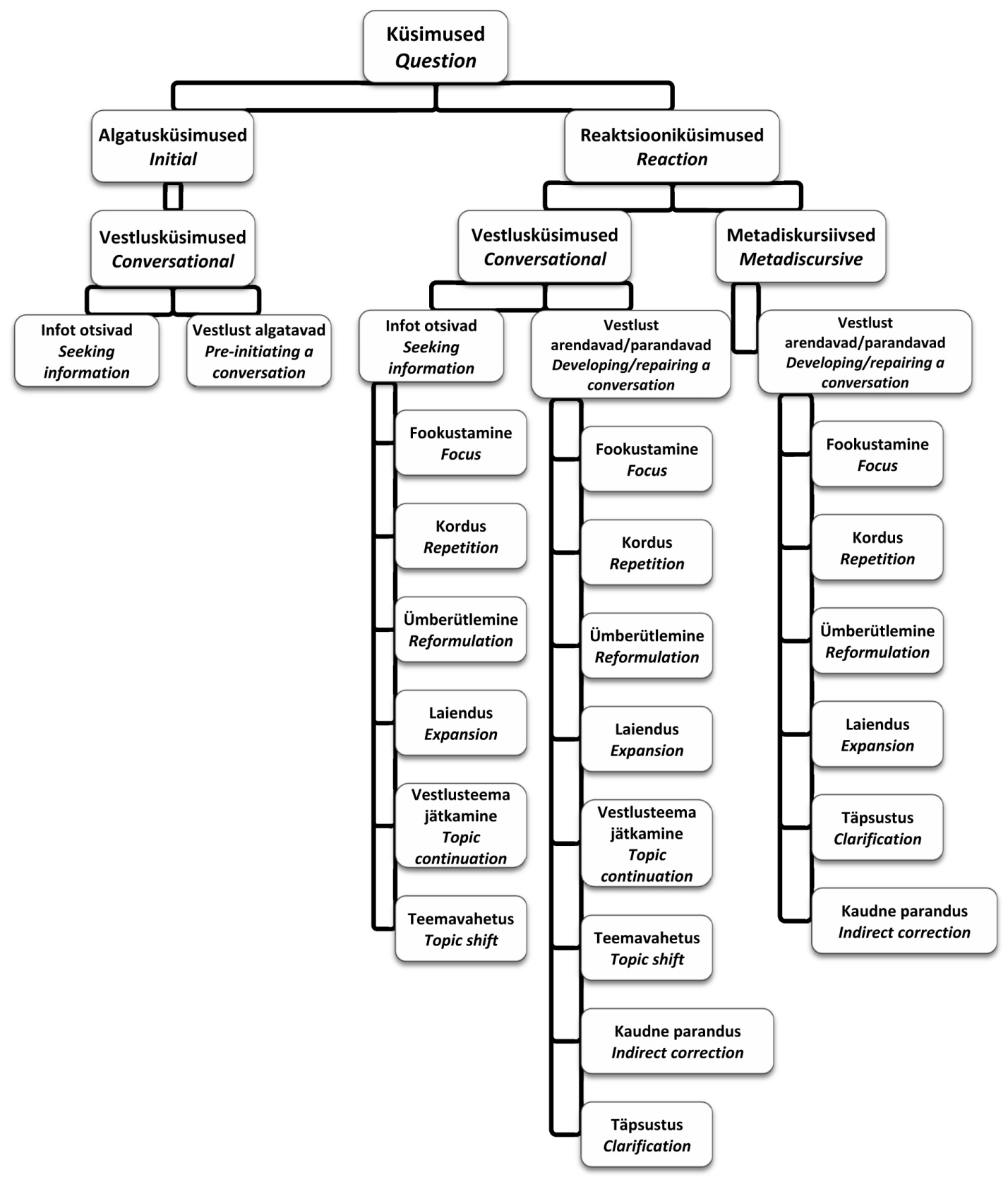

Joonis 1. Küsimuste liigitus (Kazakovskaja, Balčiūnienė 2012b: 202)

3) funktsioon - algatusküsimused jagunevad oma funktsiooni järgi kaheks: infot otsivateks (seeking information) ja vestlust algatavateks küsimusteks (pre-initiating a conversation). Reaktsiooniküsimustest jagunevad vestlusküsimused samuti kaheks: infot otsivateks ning vestlusteemat arendavateks ja parandavateks küsimusteks (developing/repairing a conversation). Infot otsiva küsimuse puhul täiskasvanu tõepoolest ei tea küsimusele vastust, nt Kus te sïs täna vanaemaga käisite?, vestlust arendava küsimuse puhul on vastus vanemale teada ja tema küsimus kannab muud eesmärki, nt Noh, mis värvi see pall on? (Viimasel juhul ei ole tegemist info otsimise, vaid vestlusteemat suunava küsimusega.) Metadiskursiivsed küsimused saavad oma struktuurilt olla vaid vestlusteemat arendavad ja parandavad; 
4) struktuur - viis, kuidas küsimuste eri struktuurid eri funktsiooni täitvate reaktsiooniküsimuste puhul jagunevad, on näidatud joonisel 1. Selle järel on lühidalt ära toodud selgitus eri struktuuride kohta.

Kazakovskaja ja Balčiūnienè liigitus (2012a: 75-78) jagab vestlusteemat arendavad ja parandavad ning infot otsivad reaktsiooniküsimused nende struktuuri järgi kaheksaks. Igale struktuuritüübile olen lisanud ka üks-kaks iseloomulikku näitelauset.

Fookustamine (ingl focus) - vanem kordab ainult osa lapse lausest:

(2) EMA: pime on jah, õhtu on käes.

LAPS: must.

EMA: must või?

Kordus (ingl repetition) - vanem kordab üle kogu lapse lausungi. Korduseks on siin loetud ainult vanema reaktsioon lapse korrektsele lausungile, muul juhul on tegu parandusega:

(3) ISA: mis sa nägid?

LAPS: mis sa otsid?

ISA: mis sa otsid?

(4) tegevus: LAPS matkib söömist, matsutab.

LAPS: oli magus.

EMA: oli magus?

Ümberütlemine (ingl reformulation) - vanem ütleb lapse lausungi ümber nii, nagu oleks parem olnud, nt muudab sõnajärge, muudab murdekeele sõna kirjakeele sõnaks, parandab onomatopoeetilise või pudikeele sõna õigeks jne. Mingit viga iseenesest ei pruugigi lapse lausungis olla. Samuti võib vanem öelda lause ümber nii, nagu ta arvas, et laps tahtis öelda:

(5) LAPS: seda maitsesid.

EMA: maitsesid seda?

Laiendus (ingl expansion) - vanem lisab midagi lapse lausele, laiendab lapse öeldut leksikaalselt või grammatiliselt:

(6) LAPS: kassi ka.

EMA: kassiraamatut ka vaatame?

Vestlusteema jätkamine (ingl topic continuation) - vanem ei korda midagi, ei paranda midagi, ei vasta otseselt lapse fraasile, vaid jätkab vestluse loomulikku kulgu:

(7) EMA: päkapikud kõnnivad õues või?

LAPS: kõnni.

EMA: mis päkapikud teevad?

Teemavahetus (ingl topic shift) - vanem ei vasta otse lapse lausungile, vaid muudab lihtsalt vestluse teemat:

(8) LAPS: Atu seda.

ISA: kas sul on piim otsas? 
(9) EMA: siia klotside juurde pissile.

LAPS: pissin passin pissi pa.

LAPS: pisin pasin.

LAPS: xxx. (Laps ütleb midagi arusaamatut.)

EMA: kus su telefon on?

Kaudne parandus (ingl indirect correction) - vanem parandab lapse eelmise lausungi vale vormi või sisu:

(10) LAPS: Ee:sti: immast.

EMA: Eesti ilmast või?

(11) LAPS: telekas oli palju kutsat.

EMA: palju kutsasid?

Täpsustus (ingl clarification) - vanem palub lapsel korrata või täpsustada eelmist lausungit:

(12) EMA: see on diktofon.

LAPS: xxx. (Laps vastab midagi arusaamatut.)

EMA: mida?

(13) LAPS: see on, mis see on?

ISA: kuskohas?

Jaotuse viies tase puudutab küsimuste jagunemist nende vormist lähtuvalt ning selle põhjal jagunevad küsimused kolmeks: üldküsimused (ingl general (yes/no) questions), mis ootavad jah/ei-vastust, alternatiivküsimused (... või/or ...) ja avatud ehk eriküsimused (wh-questions), millele vastates tuleb valida lausekomponendi etteandmata variantide vahel. ${ }^{4}$ Siinse artikli aluseks olnud 2012. aasta vene-leedueesti võrdlevas uurimuses küsimuste vormilist jaotumist ei vaadeldud, kuid kindlasti võiks seda uurida edaspidi.

\subsection{Tulemuste võrdlus}

Kui välja arvata küsimuste hulga eelmainitud erinevus eri rahvusest vanemate kõnes, olid näitajad eri keelte materjalis üldjoontes üsna sarnased. Algatusküsimusi esines vene hoidjakeeles $0,3 \%$, leedu keeles $0,2 \%$ ja eesti keeles $0,6 \%$, millest järeldub, et reaktsiooniküsimusi oli vastavalt vene keeles 99,7\%, leedu keeles 99,8\% ja eesti keeles 99,4\%. Sama vähe (o,3\%) esines eesti hoidjakeeles ka metadiskursiivseid küsimusi, mida leedu vanem kasutas 11,1\% ja vene vanem 7,7\% kõigist juhtudest.

Infot otsivate ehk n-ö tõeliste küsimuste hulk oli eesti hoidjakeeles oluliselt väiksem kui teistes keeltes - eesti keeles 1,3\%, vene keeles 8,7\% ja leedu keeles koguni 13,3\%. Kõrvutades neid andmeid eesti keele suulise kõne dialoogide uurimise

4 Eesti keele küsilausete jagunemist vormi järgi on käsitlenud Helle Metslang ja Tiit Hennoste töörühm. Metslangi $(1981,2013)$ järgi jagunevad eesti keele küsimused laiemalt samuti üld-, alternatiiv- ja eriküsimusteks, kõigi kolme küsimusevormi mõisted vastavad Kazakovskaja ja Balčiūnienè (2012b: 206) omadele. Põhitüüpide all toob Metslang lisaks välja alltüüpe.

Hennoste jt (2009: 341, 344-345) esitavad jaotuse, mis koosneb kuuest küsimusetüübist. Esmalt koosnes liigitus kolmest rühmast, mis samuti vastavad Kazakovskaja ja Balčiūniené liigitusele (kas-küsimused, alternatiivküsimused ja avatud küsimused), kuid dialooge ja neis sisaldunud küsimusi analüüsides tuli esmast jaotust laiendada ning tulemuseks saadi järgmine jaotus: 1) avatud küsimused, 2) alternatiivküsimused, 3) suletud kas-küsimused (vastuseks jaatus-eitus), 4) vastust pakkuvad küsimused (küsimus sisaldab küsija arusaama või oletust võimaliku õige või sobiva vastuse kohta), 5) jutustavad kas-küsimused (tavapärase jaatuse-eituse asemel info otsimine), 6) muud (nt analüüsimatud näited ja lausungid, kus on koos kaks küsimust jne). 
andmetega (Hennoste jt 2013: 23) selgub, et viimastes esineb infot otsivaid küsimusi $37 \%$ kõigist juhtudest. Kuivõrd Hennoste jt uurimus põhineb aga nimelt infodialoogidel (lindistatud kõned infotelefonile, reisibüroosse, polikliinikusse jne, kuhu inimene helistab tavaliselt selleks, et vajalikku infot saada), jääb üle imestada koos autoritega, mis võib olla põhjuseks, et isegi infodialoogides esineb nii vähe infot otsivaid suhtlustegevusi (Hennoste jt 2013: 24). Selliste tulemuste taustal ei tundugi ehk infot otsivate küsimuste nii vähene hulk hoidjakeeles kummaline. Igal juhul lubavad tulemused järeldada, et eesti täiskasvanu lapsega rääkides pigem suunab vestlust ega soovi infot hankida, samuti ei kipu ta last ka ülemäära parandama.

Struktuuritüübi järgi jagunesid küsimused eri rahvusest vanemate keelekasutuses enam-vähem võrdselt (vt joonis 2), esiletoomist vajaks ehk vaid see, et eesti hoidjakeeles kasutati võrreldes teiste keeltega erakordselt suurel hulgal (19,5\%) laiendavaid küsimusi (14), (15), (16) ning märkimisväärselt väikesel hulgal (0,4\%) ümberütlevaid küsimusi (17), (18), (19).

(14) LAPS: lomme. /loeme/

EMA: missugust juttu loeme?

(Andreas, $1 ; 08.25$, emaga)

(15) LAPS: see kingutus.

EMA: pakid kingituse ära vä?

(Andreas, 2;00.16, emaga)

(16) LAPS: Atsu taab veel seda.

EMA: veel sousti ja kartulit?

(Andreas, 2;01.08, emaga)

(17) LAPS: notsu limpsis notsu limpsis kaks selme.

EMA: kaks sõrme limpsis?

(Andreas, 2;01.01, emaga)

(18) LAPS: seda vanat albumit, seal on väikesed Goorgid.

EMA: väikesed Georgid on seal?

(Andreas, 2;06.12, emaga)

(19) LAPS: sõidame bussiga.

EMA: bussiga sõidame?

(Andreas, 2;07.12, emaga)

Analüüsist (vt joonis 2) selgus, et kui leedu vanem on väga aldis lapse öeldut täpsustama (kõige sagedasem küsimusestruktuur leedu keele andmete põhjal), siis nii eesti kui ka vene täiskasvanu kasutab pigem vestlusteemat laiendavaid küsimusi, mida esineb mõlema keele materjalis kõige rohkem. Vahe on aga selles, et eesti täiskasvanu laiendab vestlusteemat kaugelt rohkem kui vene täiskasvanu (eesti 19,5\% vs. vene 9\%), kuid kasutab samas silmatorkavalt vähem kordavaid ja ümberütlevaid küsimusi. 


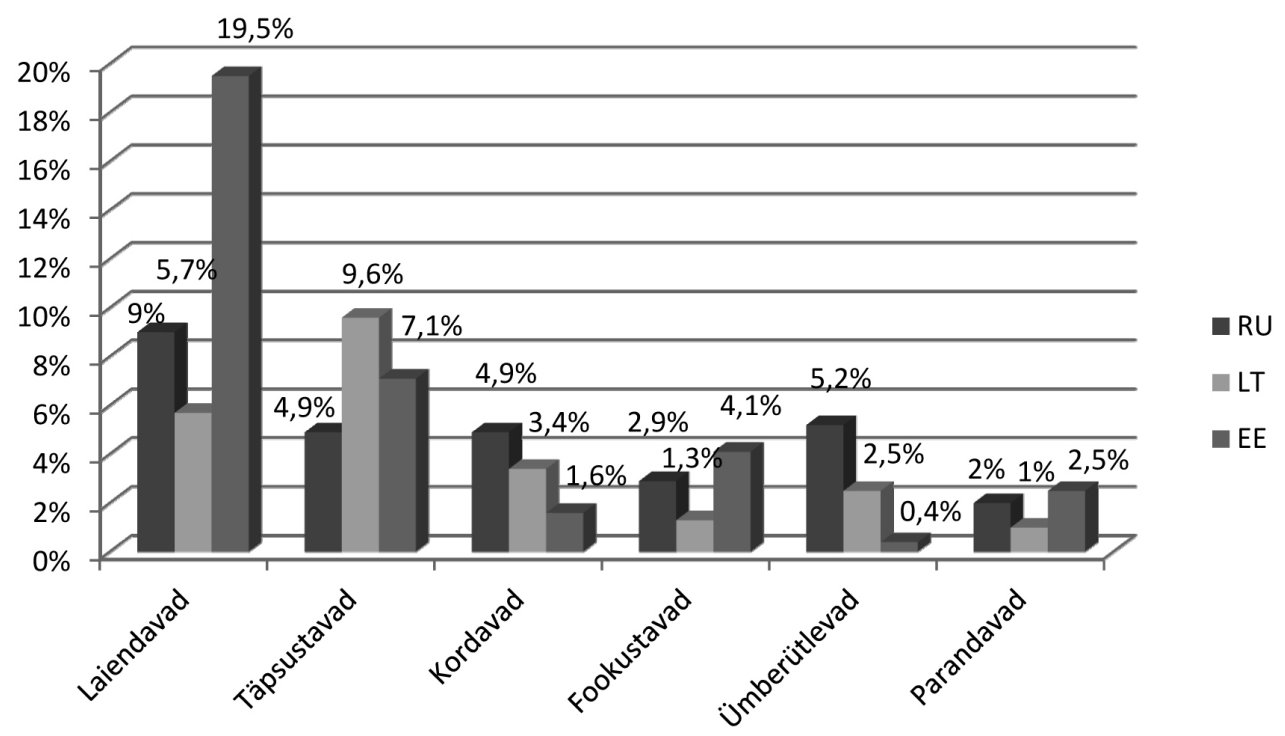

Joonis 2. Küsimuste jagunemine vene (RU), leedu (LT) ja eesti (EE) hoidjakeeles nende struktuuri järgi

\section{Eesti küsimuste analüüs täpsustatud liigitamispõhimõtete alusel}

Juureldes siiski eesti hoidjakeele küsimuste vähesuse üle ning analüüsides andmeid üha uuesti, jäi silma võimalik põhjus, miks 2012. aasta ühisuurimuse analüüsiosas kasutatud küsimuste liigitus eesti keele küsimuste määramiseks sugugi sobida ei pruugi. Küsimuste liigitamisel kehtis nõue, et analüüsimisele kuuluvad ainult need täiskasvanu küsimused, mis järgnevad vahetult lapse lausungile. Eesti hoidjakeele andmete hilisemal vaatlusel selgus aga, et täiskasvanul on sageli kombeks hoopis iseenda varasemat lausungit/küsimust küsimusega ümber öelda, täpsustada, korrata vm.

(20) EMA: mis on must?

LAPS: ake.

EMA: miks aken on must?

EMA: miks aken must on?

(21) LAPS: metsa.

EMA: metsas.

EMA: mis metsa sees on?

(22) LAPS: kepsega.

EMA: küpsetavad.

EMA: mis päkapikud küpsetavad?

EMA: mida päkapikk küpsetab?

Sellele leiule tuginedes tekkiski mõte jagada küsimused nende positsiooni järgi mitte kaheks, vaid kolmeks: algatusküsimusteks ning reaktsiooniks a) lapse eelmisele lausungile ning b) vanema enda eelmisele lausungile. Kuna vestlust analüüsides selgus, et vanem ütleb sageli küsimusega ümber hoopis iseenda öeldut või kordab 
iseenda eelmist lausungit, võis oletada, et kui võtta arvesse ka need küsimused, kasvab küsimuste üldine hulk hoidjakeeles märgatavalt. Sellest lähtuvalt otsustasin eesti hoidjakeele küsimuste määramiseks täiendada Kazakovskaja ja Balčiūnienė liigitust lisajaotisega ning viia läbi kontrolluurimuse, mis võimaldaks arvesse võtta ka vanema enda eelmisele lausungile järgnevaid küsimusi.

Selleks lisasin määramistabelisse pragmaatilise rolli reale reaktsiooniküsimuste kõrvale veel teisegi võimaluse: self reaction ehk reaktsioon iseenda kõnevoorule. Kogu muu jaotus, mis puudutas küsimuste edasist jagunemist nende funktsiooni, struktuuri ja vormi järgi, jäi samaks. Kontrolluurimuses analüüsisin 15 lindistust lapse vanuses $1 ; 7-2 ; 8^{5}$ (sh 13 lindistust emaga ja kaks isaga) ning võtsin vaatluse alla liigituse kolm esimest tasandit: küsimuste positsiooni, pragmaatilise rolli ja funktsiooni.

Võrreldes uusi tulemusi eelmistega selgus, et kui varem esines vanema kõnes 957 küsimust, siis uue jaotuse alusel oli võimalik määrata kõik 1201 küsimust (ülevaade tulemuste kohta on toodud tabelis 2). Küsimused, mis on reaktsiooniks vanema enda eelmisele lausungile, moodustavad u 20\% kõigist küsimustest, seega oli eelmise jaotuse alusel jäänud määramata ja analüüsimata viiendik vanema küsimustest. Uus liigitus ei muutnud algatusküsimuste arvu, infot otsivate küsimuste arv oli kasvanud kahe ja metadiskursiivsete küsimuste hulk kolme võrra. Kõige rohkem muutus (lisandus 244 küsimust), nagu võiski arvata, just vestlusteemat arendavate ja parandavate reaktsiooniküsimuste hulk.

(23) LAPS: panen kinni selle.

EMA: ära pane, sa pidid oma arvutiga numbreid tegema.

EMA: kus su arvuti on?

(Andreas, 2;03.26, emaga)

(24) LAPS: anna sealt ülevalt.

EMA: siit kapist, näed sul on ka sinikas siin.

EMA: oled ära löönud?

(Andreas, 2;05.30, emaga)

(25) LAPS: tead, mis kondi sees on?

EMA: ei tea.

EMA: mis seal sees on?

(Andreas, 2;07.12, emaga)

Tabel 2. Tulemuste jagunemine eesti keele materjalis varasema ja täpsustatud liigituse põhjal

\begin{tabular}{|c|c|c|c|c|}
\hline \multirow{2}{*}{$\begin{array}{c}\text { Küsimuste } \\
\text { jagunemine }\end{array}$} & \multicolumn{2}{|c|}{ VARASEM LIIGITUS } & \multicolumn{2}{|c|}{ TÄPSUSTATUD LIIGITUS } \\
\hline & $\begin{array}{l}\text { Küsimuste } \\
\text { arv }\end{array}$ & $\begin{array}{c}\text { \% kõigist } \\
\text { küsilausungitest }\end{array}$ & $\begin{array}{c}\text { Küsimuste } \\
\text { arv }\end{array}$ & $\begin{array}{c}\text { \% kõigist } \\
\text { küsilausungitest }\end{array}$ \\
\hline Küsimusi kokku & 957 & $100 \%$ & 1201 & $100 \%$ \\
\hline Algatusküsimusi & 5 & $0,5 \%$ & 5 & $0,4 \%$ \\
\hline Reaktsioone lapsele & 952 & $99,5 \%$ & 952 & $79,3 \%$ \\
\hline Reaktsioone iseendale & - & - & 244 & $20,3 \%$ \\
\hline
\end{tabular}


Kokkuvõtteks võib öelda, et uus küsimuste liigitus võimaldab määrata kõik küsimused ning saada paremat ettekujutust selle kohta, kuidas, miks ning mida vanem küsib. Küsimuste hulk vanema kõnes suureneb sellise liigituse alusel viiendiku võrra. Uurimise tulemustest selgus, et eesti vanem kordab ja sõnastab sageli ümber just enda öeldut. Samas tuleb siiski tõdeda, et ehkki uue liigituse järgi sai ära määrata veel 244 küsimust ning küsimuste osakaal vanema kõnes tõusis seetõttu 36,2 protsendini (kasvas 7,4\% võrra), on seda ikkagi märkimisväärselt vähe võrreldes vene $(51,8 \%)$ ja leedu $(71,9 \%)$ hoidjakeelega.

\section{Eesti tulemuste kontroll võrdluses laia valimi meetodil saadud keelematerjaliga}

Eeltoodud tulemuste valguses tekkis siiski küsimus, miks on vene-leedu ning eesti tulemuste vahel nii suur erinevus. Kuna 2012. aasta ühisuurimuse keeleandmed pärinesid vaid ühe ema ja tema lapse vahelisest vestlusest, jäi kahtlus, et küsimuste vähesus hoidjakeeles on tingitud selle konkreetse ema keelekasutusest. Et seda välistada, oli tarvis läbi viia teinegi kontrolluuring võrdleva materjali põhjal, mis kinnitaks või lükkaks ümber, kas eesti hoidjakeel on tõepoolest küsimustevaene. Selle tarbeks otsustasin võrrelda olemasolevaid andmeid veel nelja sama vana lapse ja nende vanemate keeleandmetega. Kuna varem kasutatud materjali mõnes lindistuses kõneles lapsega ema, mõnes aga isa, valisin ka võrdlevat materjali selle alusel, et vestluse täiskasvanud osapoolena oleksid esindatud nii isad kui ka emad. Võrdleva materjali põhjal tehtud uurimuses ei vaadelnud ma küsimuste jagunemist nende positsiooni, funktsiooni, pragmaatilise rolli ega struktuuri seisukohast, vaid keskendusin küsimuste hulga täpsustamisele.

Teise katse valim hõlmas ajaperioodilt laste teise eluaasta esimest poolt ning jagunes kolmeks vanusevahemikuks, igast vahemikust kuulus valimisse $2-4$ vestlust.

I vanusevahemik:

Andreas 2;01.03 (vestlus toimus isaga)

Martina 2;01.17 (vestlus toimus emaga)

Ruuben 2;02.03 (vestlus toimus isaga)

II vanusevahemik:

Andreas 2;03.26 (vestlus toimus isaga)

Mia 2;03.17 (vestlus toimus emaga)

III vanusevahemik:

Andreas 2;04.13 (vestlus toimus isaga)

Andreas 2;05.02-2;05.30 (vestlus toimus emaga)

Jaana 2;05.12 (vestlus toimus emaga)

Kõigis kolmes vanusegrupis olen aluseks võtnud esmalt algses uurimuses kasutatud lapse, Andrease kõneandmed, millele olen võrdlusmaterjalina lisanud teiste sama vanade laste ja nende vanemate kõneandmed lähtuvalt sellest, mis vanuses laste ja vanemate spontaankõne lindistuste litereeringuid pakub CHILDESi lastekeele andmebaasi eesti lastekeele korpus. Andmete analüüsimisel kasutasin enda täiendatud küsimuste liigitust (vt eespool 3. osa). Ülevaate tulemustest annab tabel 3. 
Tabel 3. Küsimuste hulk hoidjakeeles laia valimi meetodi põhjal

\begin{tabular}{|c|l|c|c|c|}
\hline $\begin{array}{c}\text { Vanuse- } \\
\text { vahemik }\end{array}$ & \multicolumn{1}{|c|}{$\begin{array}{c}\text { Lapse nimi } \\
\text { ja vanus }\end{array}$} & $\begin{array}{c}\text { Lausungite } \\
\text { arv }\end{array}$ & $\begin{array}{c}\text { Küsimuste } \\
\text { arv }\end{array}$ & $\begin{array}{c}\text { Küsimuste } \\
\text { osakaal }\end{array}$ \\
\hline \multirow{3}{*}{ I } & Andreas 2;01.03 & 393 & 84 & $21,4 \%$ \\
\cline { 2 - 5 } & Martina 2;01.17 & 418 & 111 & $26,6 \%$ \\
\cline { 2 - 5 } & Ruuben 2;02.03 & 447 & 140 & $31,3 \%$ \\
\hline \multirow{3}{*}{ II } & Andreas 2;03.26 & 130 & 48 & $36,9 \%$ \\
\cline { 2 - 5 } & Mia 2;03.17 & 539 & 193 & $35,8 \%$ \\
\hline \multirow{3}{*}{ III } & Andreas 2;04.13 & 182 & 55 & $30,2 \%$ \\
\cline { 2 - 5 } & Jaana 2;05.12 & 357 & 103 & $28,9 \%$ \\
\cline { 2 - 5 } & Andreas 2;05.02-.30 & 343 & 89 & $26 \%$ \\
\hline \multirow{2}{*}{ Kokku / keskmine } & $\mathbf{2 8 0 9}$ & $\mathbf{8 2 3}$ & $\mathbf{2 9 , 3 \%}$ \\
\hline
\end{tabular}

Analüüsitulemused näitavad, et teised valimisse kuulunud vanemad kasutavad tõepoolest rohkem küsimusi, kuid see ei muuda siiski märkimisväärselt küsimuste hulga osakaalu kõigi lausungite hulgas (st teistes lindistustes oli proportsionaalselt suurem ka täiskasvanu lausungite koguhulk). Niisiis kinnitab laia valimi põhjal tehtud kontrolluuring samuti, et 2-aastase lapsega kõneldes kasutab eesti täiskasvanu vaid keskmiselt 29,3\% küsimusi. Seega ei saa küsimuste vähesust hoidjakeeles pidada vaid ühe konkreetse vanema keelekasutuse eripäraks. Niisugune tulemus kinnitab veel kord, et eesti hoidjakeel on tõepoolest küsimustevaene ning selle vestlusstrateegiad ei ole üles ehitatud peamiselt ega ka mitte suuremalt jaolt küsimustele, nagu võime näha vene ja leedu hoidjakeele tulemustest.

\section{Kokkuvõtteks}

Küsimuste kasutamise sageduse põhjal võib väita, et eesti hoidjakeel sarnaneb pigem meist geograafiliselt kaugemate germaani ja romaani keeltega, mis on üles ehitatud peamiselt väit- ja käsklausetele ning kordustele, mitte niivõrd küsimustele nagu meile geograafiliselt lähemad balti ja slaavi keeled. Samas võib öelda, et küsimuste vähesest kasutamisest hoolimata sarnaneb nende üldine jaotumine vastavalt küsimuse positsioonile (enam kui 99\% reaktsiooniküsimusi), funktsioonile (ligi 90\% vestlusküsimusi), pragmaatilisele rollile (ligi 90\% vestlusteemat arendavaid ja parandavaid küsimusi) ja struktuurile (kõige rohkem on kõigis kolmes keeles kasutatud vestlusteemat laiendavaid ja jätkavaid küsimusi) eesti hoidjakeeles vene ja leedu keelega.

Siiski ei võimalda keelematerjali piiratus praegu teha põhjapanevaid järeldusi kultuuriliste ühisjoonte või meie ühise nõukogude tausta võimaliku mõju kohta eesti, vene ja leedu hoidjakeelele. Selleks tuleks kindlasti uurida ka vene ja leedu hoidjakeelt laia valimi abil ning välistada sel moel neiski keeleandmetes võimalus, et küsimusterohke suhtlusstiil iseloomustab tegelikult ainult ühte konkreetset vanemat. Vene materjali puhul võib olulist rolli mängida fakt, et lapse vestluspartner on vanaema, mitte ema. 
Veel oleks edaspidi huvitav vaadata, kuidas muutub vanema kõnes küsimuste hulk, nende funktsioon ja pragmaatiline roll lapse kasvades, aga ka seda, kas ja kuidas see peegeldub lapse kõnes. Samuti oleks huvitav võrrelda neid aspekte vene ja leedu lapsele suunatud kõne andmetega.

\section{Viidatud kirjandus}

Argus, Reili 2003. Lastekeelest ja selle uurimisest. - Oma Keel, 1, 26-32.

Hennoste, Tiit; Gerassimenko, Olga; Kasterpalu, Riina; Koit, Mare; Rääbis, Andriela; Strandson, Krista 2009 Küsimused eestikeelses infodialoogis I: küsimuste vorm. - Keel ja Kirjandus, 5, 341-359.

Hennoste, Tiit; Andriela Rääbis; Kirsi Laanesoo 2013. Küsimused eestikeelses infodialoogis II: küsimused ja tegevused. - Keel ja Kirjandus, 1, 7-28.

Kazakovskaja, Viktoria; Balčiūnienė, Ingrida 2011. Ossobennosti retši vzroslovo, obraššennoi $\mathrm{k}$ rebjonku: voprossitelnõje repliki v russkom i litovskom jazõkah. - Isljedovanija po slavjanskim jazõkam, 16 (1), 259-292.

Kazakovskaja, Viktoria; Balčiūnienė, Ingrida 2012a. Lithuanian and Russian child-directed speech: Why do we ask young children so many questions? - Eesti Rakenduslingvistika Ühingu aastaraamat, 8, 69-89. http://dx.doi.org/10.5128/ERYa8.05

Kazakovskaja, Viktoria; Balčiūnienè, Ingrida 2012b. Interrogatives in Russian and Lithuanian child-directed speech: Do we communicate with our children in the same way? - Journal of Baltic Studies, 43 (2), 197-218

Kazakovskaja, Viktoria; Balčiūnienė, Ingrida; Kõrgesaar, Helen 2012. Conversational strategy in early childhood: Insights into Estonian, Lithuanian and Russian child-directed speech. - Ettekanne 16.-18.5.2012 Tallinna Ülikoolis toimunud rahvusvahelisel konverentsil "Keeleteaduse päevad 2012".

Kilani-Schoch, Marianne; Balčiūnienė, Ingrida; Korecky-Kröll, Katharina; Laaha, Sabine; Dressler, Wolfgang U. 2009. On the role of pragmatics in child-directed speech for the acquisition of verb morphology. - Journal of Pragmatics, 41 (2), 219-239. http:// dx.doi.org/10.1016/j.pragma.2008.10.001

Kõrgesaar, Helen 2007. Lapsele suunatud kõne võrdlus lapse ja täiskasvanule suunatud keelekasutusega. Seminaritöö. Käsikiri Tallinna Ülikoolis.

Metslang, Helle 1981. Küsilause eesti keeles. [Interrogative sentence in Estonian.] Tallinn: Valgus.

Metslang, Helle 2013. "Kes palju küsib, saab targemaks." Küsimusest ja selle keelelisest vormist. ["Who asks a lot, can be smarter." Question and its linguistic form.] - Oma Keel, 2, 5-12.

Mägiste, Julius 1924. Paar sõna lastekeelest. - Eesti keel, 1, 1-9.

Pajusalu, Karl 2001. Baby Talk as a Sophisticated Register: A Phonological Analysis of South Estonian. - Psychology of Language and Communication, 5 (2), 81-92.

Tulviste, Tiia 2000. Socialization at meals: A comparison of American and Estonian motheradolescent interaction. - Journal of Cross-Cultural Psychology, 31 (5), 537-556. http:// dx.doi.org/10.1177/0022022100031005001

Tulviste, Tiia; Kants, Luule 2001. Conversational styles of mothers with different value priorities: Comparing Estonian mothers in Estonia and Sweden. - European Journal of Psychology of Education, 16 (2), 223-231. http://dx.doi.org/10.1007/BFo3173027

Tulviste, Tiia; Mizera, Luule 2002. Eesti emad, Rootsi lapsed: võrdlev uurimus sotsialisatsioonist eesti, rootsi ja soome üks- ja kakskultuurilistes kodudes. - Aune Valk (Toim.). Eesti ja eestlased võrdlevas perspektiivis: kultuuridevahelisi uurimusi 20. sajandi lõpust. Tartu Ülikool: Tartu Ülikooli Kirjastus, 143-155. 
Tulviste, Tiia; Mizera, Luule; De Geer, Boel; Tryggvason, Marja-Terttu 2002. Regulatory comments as tools of family socialization: A comparison of Estonian, Swedish and Finnish mealtime interaction. - Language in Society, 31 (5), 655-678. http://dx.doi. org/10.1017/Soo47404502315045

Helen Kõrgesaar (Tallinna Ülikool) uurib eesti hoidjakeelt, selle dünaamikat ja mõju lapse kõne arengule.

Narva mnt 25, 10120 Tallinn, Estonia

helen.korgesaar@gmail.com 


\title{
INTERROGATIVES IN ESTONIAN CHILD-DIRECTED SPEECH
}

\author{
Helen Kõrgesaar
}

Tallinn University

It has been established from previous studies that Estonian child-directed speech includes fewer questions than in Russian and Lithuanian and adults' interaction with children is based on declarative and command sentences, which aligns Estonian child-directed speech more closely to Germanic and Romance languages than to the geographically closer Baltic and Slavic languages. The aim of the present article is to find out whether Estonian child-directed speech is indeed as poor in questions as it appeared by initial research.

Analysing the Estonian data from previous research, it appeared that Estonian adults do not use questions only in reaction to child speech but also to reformulate, specify and repair their own utterances. For that reason the original classification of questions used in this research has been refined. To the previous classification that only took into account questions that the parent posed in immediate reaction to the child's speech, a new category has been added in order to consider the questions that parents pose in reaction to their own prior utterances.

The Estonian-Russian-Lithuanian joint study was based on speech data from one Estonian, one Russian and one Lithuanian child-parent couple. About 12 hours of audio material for each language was observed, all three children were recorded at age 1;8-2;8. First, for a control study, 15 recordings of one-hour spontaneous speech of children aged 1;7-2;8 were analysed. Then, the results were verified by a wide selection method and speech data from another four children was included, in order to exclude the possibility that the small number of questions characterizes the phrasing of a specific mother rather than that of Estonian child-directed speech in general.

The results of the study show that although the new classification of questions allowed the identification of one-fifth more questions, Estonian child-directed speech compared to Russian and Lithuanian child-directed speech remains relatively poor in questions and according to its conversation strategy is more similar to Germanic and Romance languages.

However, it can be said that according to the position, function, pragmatic role and structure, the results concerning the overall distribution of questions in Estonian child-directed speech are similar to Russian and Lithuanian results.

Keywords: language acquisition, pragmatics, Estonian, Russian, Lithuanian 